\title{
The human side of the triangle: using green textile standards to address social responsibility
}

\author{
J. Stark ${ }^{1} \&$ M. Cudhea ${ }^{2}$ \\ ${ }^{I}$ College of Visual Arts \& Design, University of North Texas, USA \\ ${ }^{2}$ College of Public Affairs and Community Service, \\ University of North Texas, USA
}

\begin{abstract}
Textile specification in the interior design field has evolved to include attributes in addition to aesthetics, cost, building occupant health and safety, and specialized performance criteria. Initially, "green" specifications addressed environmental impact reduction through renewable, recycled, recyclable, nontoxic and low-emitting materials. Worldwide, third-party certifications continue to expand sustainable attributes to include social equity impacts on human health, safety, training and compensation throughout the product life cycle. Comprehension of these new assessment tools is essential for designers to effectively balance economic, environmental, and social responsibility.

Although social responsibility has been discussed in the context of global sustainable development since the 1970s, third-party evaluation attempts to systematically connect the effects of product manufacture, use, and disposal to the human condition are relatively recent. Environmental and social impacts are interrelated, but not interchangeable. Social equity criteria are not addressed uniformly in textile certifications. This paper presents research on designers' perceptions of social responsibility, awareness of social issues in the textile life cycle, and prioritization of textile specification criteria. The study also considers to what extent designers take responsibility for sustainable design decisions, and if sustainable design is becoming a standard practice. The analysis focuses on responses generated by a questionnaire distributed through an online interior design publication based in Texas (USA) and distributed internationally.

Keywords: social responsibility, interior design, life cycle assessment, material selection, sustainable textile standards.
\end{abstract}




\section{Introduction}

Spiegel and Meadows [1] have documented the attribute-based approach for green building product specification. Broadening business bottom-line economic goals to include both social and environmental benefits has evolved from early triad models by Elkington [2] and Lovins and Lovins [3] to those more specifically aligned with design as described by Bonda and Sosnowchik [4] and Pearson [5]. Currently, The Green ${ }^{\mathrm{TM}}$ Standard is developing specification tools for the global market that acknowledge U.S. Environmental Protection Agency environmental impact categories and expand a single attribute approach to focus on life cycle assessment [6]. Pearson [7] encourages more in-depth analysis to understand the complexities of human and ecosystem health throughout the product supply chain, for example, raw material processes, manufacture, delivery, installation, maintenance, and disposal. As Wendt [8] points out, "discussion of sustainability in the green building industry often focuses on the first two legs of the stool - economy and environment - with discussion of equity occurring only in relation to occupant health and other immediate concerns." The current understanding of social equity extends beyond end user well being and embraces labour practices supporting fair or competitive wages and human rights concerns for safe work environments and equitable living standards for all those impacted throughout the product life cycle.

Although educational and professional standards dictate that interior designers take responsibility for sustainable design decisions, the studies done on designer attitudes reveal inconsistencies in what designers say they should be doing and actual practice. In her discussion of the "state of the contemporary interior," Beecher [9] cites a 2000 Interior Design study which reports that 83 percent of designers surveyed believed they had a moral obligation to offer environmentally responsible solutions to their clients although only 37 percent indicated they actually did so. In their study of interior design practitioners in the American Society of Interior Designers, Kang and Guerin [10] found that in a series of statements on global interior design practice, indoor environmental quality and interior materials, "every statement showed the highest mean score in the category of importance to designer and the lowest mean score in the category of frequency of application." Steig [11] has identified this phenomenon as "the sustainability gap [which] exists between theory and practice: between what we believe to be right and what we know to be right; between how we should practice sustainable design and how we are able to practice it." The gap is based in a deficiency of reliable data combined with an overwhelming amount of information, limited access to transparent evaluative tools and a lack of critical analysis skills to fully understand and integrate them meaningfully into the interior design process [12]. Other perceived obstacles to a sustainable approach are client unwillingness, restricted aesthetic choices, and higher cost [13].

Using textile specification as a lens can be instructive in understanding designers' awareness of social responsibility issues and the extent to which these issues are becoming part of sustainable design practice. 


\section{Framework}

Although many nuances exist in language and definition, there is general agreement that sustainable development practices require a balance of economic, environmental and social impacts. This "triple bottom line" $[14,15]$ approach provided the context for an online survey questionnaire, Social Responsibility and Interior Design. The instrument included quantitative and qualitative items and was structured in four sections: Social Responsibility and Textile Specification, Sustainable Design Practice, Business Profile, and Demographic Profile.

Primary investigative question:

To what extent are interior designers aware of social responsibility issues?

In general:

- How do designers define social responsibility

- To what extent are social responsibility attributes considered for project work

Specifically related to textiles:

- To what extent are social responsibility attributes considered individually and relative to other attributes

- To what extent are social responsibility life cycle issues considered individually and relative to environmental impact life cycle issues

- What is the level of awareness held by interior designers of options for sustainably designed textiles?

- Familiarity with related agencies, standards \& certifications

- What do designers value in certification criteria

- What are designers' sources of information

- What influences designers to reference sustainable certifications

- What influences designers to specify sustainably designed textiles

Secondary investigative question:

Is sustainable design becoming a "best practice"?

- What factors influence designers' sustainable design decisions

- To what extent are designers taking responsibility for sustainable decisions

- Is there evidence of a "sustainability gap"?

\subsection{Population and sampling method}

Data were obtained for this research using a convenience sample of respondents from the contacts of PLiNTH \& CHiNTZ, The Online Interior Design Magazine. 
This publication provides advice on industry issues for current design students, new design graduates, design educators, and professional practitioners in design or affiliated industries such as design-related sales and service. According to the magazine's internal data, P \& C attracts tens of thousands of readers per month from over 25 countries (primarily from the United States, followed by the United Kingdom, Australia and The Netherlands). Readers are both male and female, have a mixed ethnic composition, and an age range of 18-65 [16]. More specific demographic data on the sample population were not available to researchers.

Invitations to participate in this online survey were distributed through an email to approximately 9,200 who have signed up to receive "special events / notices", a prominent post on plinthandchintz.com, and a follow-up reminder in the magazine's monthly email newsletter, which goes out to approximately 9,900 who have signed up to receive it. Due to logistical limitations, a randomly selected sample was not obtainable. In addition, since the total number of "invited" respondents is unknown (due to the advertising methods described above and an unknown degree of overlap) a response rate cannot be calculated. However, given the exploratory and broad sweep of this investigation, generalizability is not a primary analysis goal and thus the non-probability sample should not be a major concern. Given this however, interpretations of tests of statistical significance should be viewed with caution. Focus in this analysis will be given to substantive significance and emergent themes.

Table 1: $\quad$ Years of experience.

\begin{tabular}{|ccc|}
\hline $\begin{array}{c}\text { How long have you worked (full or part-time) } \\
\text { in the interior design industry? }\end{array}$ & Frequency & $\begin{array}{c}\text { Valid } \\
\text { Percent }\end{array}$ \\
\hline Still in/just out of school and not employed & 15 & 15.5 \\
\hline 1-2 years & 12 & 12.4 \\
\hline 3-5 years & 10 & 10.3 \\
\hline 6-10 years & 13 & 13.4 \\
\hline 11-20 years & 14 & 14.4 \\
\hline 21+ years & 33 & 34.0 \\
\hline Total & $\mathbf{9 7}$ & $\mathbf{1 0 0 . 0}$ \\
\hline
\end{tabular}

Table 2: $\quad$ Work activity.

\begin{tabular}{|ccc|}
\hline Project type work activity & Frequency & $\begin{array}{c}\text { Valid } \\
\text { Percent }\end{array}$ \\
\hline $100 \%$ Residential & 13 & 13.4 \\
\hline $75 \%$ Residential $/ 25 \%$ Commercial & 20 & 20.6 \\
\hline $50 \%$ Residential $/ 50 \%$ Commercial & 11 & 11.3 \\
\hline $25 \%$ Residential/75\% Commercial & 9 & 9.3 \\
\hline $100 \%$ Residential & 24 & 24.7 \\
\hline Total & $\mathbf{9 7}$ & $\mathbf{1 0 0 . 0}$ \\
\hline
\end{tabular}




\subsection{Description of the sample}

$72.2 \%$ of respondents are practicing (full or part time) interior designers, with the remainder composed of students $(12.4 \%)$, recent graduates not working in the industry $(7.2 \%)$, educators $(6.1 \%)$, and design industry affiliates $(2.1 \%)$. See Table 1 for years of experience.

$38.1 \%$ are self-employed and $41.2 \%$ work for a company or institution. $57.7 \%$ responded that they did not work on any international projects. See Table 2 for percentages of work activity.

Designers were questioned about what percentages of their project work involves sustainable design strategies, green product specification, green building programs, and attention to socially and environmentally responsible issues. They were also asked to characterize their approach to these practices.

Demographically, respondents were U.S. residents (96.9\%), Caucasian American (87.6\%), female $(85.6 \%)$, married $(62.9 \%)$, $45+$ years of age $(49.5 \%)$ with a bachelors degree (59.8\%). $41.2 \%$ have 1 to 2 children and $46.4 \%$ have none.

\subsection{Analysis methods}

Regression analysis was performed on data gathered on the quantitative items from the 97 respondents. Variables were constructed to describe relationships between levels of social responsibility awareness and design practice behaviours. For the qualitative comments, a particular goal was to "identify themes and subthemes," in order to gain insights from this study which will become the basis for future analysis [17]. Using a cutting and sorting technique, categories were identified based on repetition of topics and comparison across responses.

\section{Findings}

\subsection{Social responsibility awareness}

The open comment answers to the initial question, "Briefly describe your understanding of 'social responsibility' as it relates to interior design," revealed several major response categories (see Table 3). "World View" responses were characterized by broad, general statements about the environment and society. "Health, safety and welfare" was a consistent theme, with more emphasis on current than future users. For design process strategies, designers were interested in balancing social responsibility with client expectations and proposing timeless solutions. Materials selection techniques ranged from a general approach favouring green specifications to detailed product attributes. Designers also discussed social responsibility as a matter of individual ethics, but acknowledged that other factors often have the last word in project decisions.

\subsection{Importance of social responsibility and the gap between independent ratings and relative rankings}

Overall, participants expressed that social responsibility was an important issue for them in specifying textiles with $77.3 \%$ ( 75 respondents) indicating social 
responsibility was very or extremely important. However, 41\% (40 respondents) still ranked social and environmental impacts as the two least important criteria in specifying textiles as they work in school or on the job. In this ranking, social impacts fared worse than environmental impacts, with 66\% (64 respondents) ranking social impacts dead last as the least important factor in specifying textiles as they work in school or on the job.

Table 3: $\quad$ Social responsibility.

\begin{tabular}{|c|c|c|}
\hline Category & Subcategory & Percent* \\
\hline \multirow{2}{*}{$\begin{array}{l}\text { World } \\
\text { View }\end{array}$} & Triple bottom line; society at large; cultural sensitivities & 5.9 \\
\hline & Do no harm to the environment & 4.6 \\
\hline \multirow{3}{*}{$\begin{array}{l}\text { Health, } \\
\text { Safety, \& } \\
\text { Welfare }\end{array}$} & HS\&W for clients; current end users & 11.2 \\
\hline & HS\&W for the general public; current population at large & 9.2 \\
\hline & HS\&W for human beings, environment over time; "future generations" & 5.3 \\
\hline \multirow{3}{*}{$\begin{array}{c}\text { Design } \\
\text { Process: } \\
\text { Strategies }\end{array}$} & Conservation; waste reduction; timeless; inclusive & 5.3 \\
\hline & $\begin{array}{l}\text { Balance client requirements and environmental resources; making } \\
\text { money and saving the environment; best value }\end{array}$ & 4.6 \\
\hline & Meet or exceed client requirements & 4.0 \\
\hline \multirow{4}{*}{$\begin{array}{c}\text { Design } \\
\text { Process: } \\
\text { Materials } \\
\text { Selection }\end{array}$} & Reduce, reuse, recycle; locally sourced; non-toxic & 11.8 \\
\hline & Sustainable approach; use green specs & 8.6 \\
\hline & LCA; how product is made & 7.9 \\
\hline & Certifications; standards & 1.9 \\
\hline \multirow{3}{*}{ Practice } & Individual ethics; responsibility to educate others; support community & 14.5 \\
\hline & $\begin{array}{l}\text { Provisional outcomes; look to others in industry to define } \\
\text { responsibility }\end{array}$ & 3.3 \\
\hline & Don't know; not sure & 1.9 \\
\hline Total & [* - 97 participants generated 152 responses] & 100.0 \\
\hline
\end{tabular}

In addition, logistic regression of the relationship between respondents' ratings of the importance of social responsibility and their likelihood of ranking social and environmental impacts anywhere above the least important factor in specifying textiles revealed no statistically significant relationship. Rating social responsibility as very or extremely important did not increase the likelihood that social impacts would be ranked above the least important factor in specifying textiles (model $\chi^{2}=1.699$, $\mathrm{Df}=1, \mathrm{p}$ value $=.192$ ), nor did it increase the likelihood that environmental impacts would be ranked above the least important factor in specifying textiles $\left(\right.$ model $\chi^{2}=2.737, \mathrm{Df}=1, \mathrm{p}$ value $\left.=.098\right)$

\subsection{Textile standards and certifications}

In 2005, the Association for Contract Textiles (ACT) began work with GreenBlue, NSF International, and ANSI to develop The Sustainable Textile Standard, scheduled for introduction in 2010 [18]. When asked what they had heard about the standard, $64.9 \%$ (84 respondents) had heard "nothing," or "very little." Designers were also asked to rate their familiarity with existing thirdparty standards. Respondents were "somewhat familiar" with the Greenguard Environmental Institute, and "not very familiar" with ISO 9000 and 14000. The 
remaining standards all received their highest scores in the lowest, the "not familiar," category: ACT; Scientific Certification Systems; C2C (MBDC), (C)2009; GreenBlue, (C2006; SMaRT(C) Sustainable Textile Standard; Global Organic Textile Standard; Eco Labels; and Environmental Product Declarations.

When asked "What is important to you about a sustainable textile standard?", designers ratings were as follows: "extremely important" - prepared by a thirdparty agency rather than a manufacturer, and applicable to a green building program such as LEED $\AA$; "very important" - evaluates multiple green attributes, evaluates environmental life cycle issues, accessible and easy to understand; and "somewhat important" - evaluates socially responsible issues.

Designers were given multiple options to choose from as the sources for most of their information about sustainably design textiles. The top four choices were market based: manufacturers' literature, websites; manufacturers' representatives; trade publications; and trade shows and exhibits.

Two open comment questions addressed influences for interior designers.

Table 4: $\quad$ Specification influences.

\begin{tabular}{|cc|}
\hline $\begin{array}{c}\text { "What influences you to specify environmentally responsible (ER) } \\
\text { and socially responsible (SR) textiles?" }\end{array}$ & Percent* \\
\hline Client request; project criteria & 28.7 \\
\hline Green product concept; green characteristics desirable; LCA issues & 15.5 \\
\hline World view of environmental stewardship and social responsibility; "good for all" & 13.2 \\
\hline Personal beliefs; ethical, moral issue; responsibility to educate client & 10.8 \\
\hline Nothing; ER and SR textiles are not used & 8.5 \\
\hline Company standards; use when ER/SR textiles are available and project compliant & 7.8 \\
\hline Manufacturers' information; third party certification & 5.4 \\
\hline LEED $§$ points & 4.7 \\
\hline Miscellaneous attributes; aesthetics, availability; country of origin; health & 3.9 \\
\hline Personal beliefs are pro ER/SR and in conflict with company & 1.5 \\
\hline [*97 respondents generated 129 responses] & $\mathbf{1 0 0 . 0}$ \\
\hline
\end{tabular}

Table 5: $\quad$ Sustainable influences.

\begin{tabular}{|cc|}
\hline $\begin{array}{c}\text { "What influences you to use sustainable textile standards or } \\
\text { certifications?" }\end{array}$ & Percent* $^{*}$ \\
\hline Third party unbiased approach; anti-greenwashing & 36.4 \\
\hline Nothing; not aware of sustainable textile standards & 27.3 \\
\hline Client request; project criteria & 19.2 \\
\hline Personal commitment; concern for environment and social responsibility & 6.0 \\
\hline Use if available; not enough available; can't convince management & 6.0 \\
\hline Recommendation by magazine or peers; promotional material; product portfolio & 5.1 \\
\hline [*97 respondents generated 99 responses] & $\mathbf{1 0 0 . 0}$ \\
\hline
\end{tabular}

\subsection{How do these attitudes affect what designers actually do?}

Several items assessed respondents' actual practices of implementing sustainable design, green specifications, and socially/environmentally responsible design practices. Respondents' ranking of the importance of social responsibility did 
seem to be statistically significantly linked with their standard approaches to incorporating sustainable design strategies (chi-square $=35.885, \mathrm{p}$ value $<.001$ ). $23 \%$ of those ranking social responsibility as "extremely important" characterized sustainable design as a standard approach required for all projects, while only $11 \%$ of those ranking social responsibility as "somewhat important" did the same. Conversely, only $10 \%$ of those ranking social responsibility as "extremely important" characterized sustainable design as offered only by client request, while $44 \%$ of those ranking social responsibility as "somewhat important" offered sustainable design approached only on client request.

Exploring this in terms of the percentage of respondents' work that was commercial revealed an interesting contradiction when this relationship disappeared for those respondents who worked primarily $(75 \%$ or more of project work) in commercial projects. For those not working primarily in commercial projects this relationship remained consistent (chi-square $=26.643, p$ value $=.002$ ). For those in commercial projects, while $37.5 \%$ of those ranking social responsibility as "extremely important" characterized sustainable design as a standard approach to every project, $25 \%$ of those ranking social responsibility as "somewhat important" did the same, a difference of only one respondent that was not statistically significant (chi-square $=3.743$, $\mathrm{p}$ value $=.711$ ).

At the same time that respondents' working primarily in commercial projects seemed to be using sustainable design approaches less on the basis of their own sense of the importance of social responsibility, they were also slightly more likely overall to report that incorporating sustainable design approaches were a part of the required standard approach to every project $(27.3 \%$ for respondents' working primarily in commercial projects vs. $21.9 \%$ for respondents' working in residential or mixed projects). While this difference was not statistically significant (chi-square $=4.055, \mathrm{p}=.256$ ), considered in light of two other items (discussed below), this difference does warrant investigation.

When asked how often their projects require attention to and actually implement social and environmental responsibility (in four separate items), respondents working primarily in commercial projects were more likely to indicate these approaches were required of them and ultimately employed by them in a greater percentage of projects, particularly in terms of environmental responsibility. Of respondents working primarily in commercial projects, $39.4 \%$ indicated that attention to environmental responsibility is always or usually required of their projects as compared to only $25 \%$ of those working in residential/mixed projects, a difference that is not statistically significant (chisquare $=9.217, \mathrm{p}=.056$ ), but is substantively large. In addition to this, working primarily in commercial projects was associated with higher percentages of projects that actually employ sustainable design and green products specification (chi-square $=12.804, \mathrm{p}=.012$ ).

Further examination of this disparity revealed a similar pattern. For all respondents higher ratings of the importance of social responsibility were associated with a higher likelihood of being required to pay attention to social responsibility issues $(\mathrm{r}=.380, \mathrm{p}<.01)$ and environmental responsibility issues. 


\section{Discussion}

Although there was some evidence of the "sustainability gap" phenomenon [19], findings differed between the contexts of textile specification and general sustainable design practice. A high rating of importance of social responsibility was not linked to assigning a higher priority to socially and environmentally responsible attributes in textile selection. Disparity between theory and practice in textile specification was also indicated in designers' lack of awareness of evaluative tools. For example, although third-party certifications are valued for their objectivity, designers rely primarily on market-based information sources. In terms of sustainable textiles, for the most part, designers are not aware of the agencies that could provide the third-party information.

Table 6: $\quad$ ER \& SR motivators.

\begin{tabular}{|c|c|c|c|c|}
\hline \multicolumn{2}{|c|}{ Motivators } & $\begin{array}{c}\text { Positive } \\
\text { Outcomes }\end{array}$ & $\begin{array}{l}\text { Negative } \\
\text { Outcomes }\end{array}$ & $\begin{array}{c}\text { Provisional } \\
\text { Outcomes }\end{array}$ \\
\hline \multirow{5}{*}{ EXTERNAL } & Client & $\begin{array}{l}\text { Client requests } \\
\text { ER/SR product }\end{array}$ & $\begin{array}{c}\text { Client rejects } \\
\text { ER/SR product }\end{array}$ & \multirow{5}{*}{$\begin{array}{c}\text { Ambivalent } \\
\text { client/project } \\
\text { requirements } \\
\text { and/or company } \\
\text { policy allows } \\
\text { ER/SR product use } \\
\text { if project criteria } \\
\text { and ER/SR } \\
\text { attributes align and } \\
\text { if suitable product } \\
\text { is available }\end{array}$} \\
\hline & Project & $\begin{array}{l}\text { Project criteria; } \\
\text { LEED }{ }^{\circledR} \text { points }\end{array}$ & $\begin{array}{c}\text { Project criteria } \\
\text { preclude ER/SR } \\
\text { product }\end{array}$ & \\
\hline & Company & $\begin{array}{c}\text { Company standard } \\
\text { practice }\end{array}$ & $\begin{array}{c}\text { Company standard } \\
\text { of low or no } \\
\text { ER/SR value }\end{array}$ & \\
\hline & Market & $\begin{array}{l}\text { Manufacturers' } \\
\text { information; peer } \\
\text { and publication } \\
\text { recommendation; } \\
\text { ease of access }\end{array}$ & $\begin{array}{c}\text { Scepticism; lack of } \\
\text { trust }\end{array}$ & \\
\hline & Third-Party & $\begin{array}{c}\text { Unbiased } \\
\text { information; } \\
\text { awareness; ease of } \\
\text { access }\end{array}$ & $\begin{array}{l}\text { Scepticism; not } \\
\text { accessible; not } \\
\text { aware }\end{array}$ & \\
\hline \multirow{3}{*}{ INTERNAL } & World View & $\begin{array}{l}\text { Environmental } \\
\text { stewardship and } \\
\text { social } \\
\text { responsibility }\end{array}$ & $\begin{array}{l}\text { No value placed on } \\
\text { ER/SR products }\end{array}$ & \multirow{3}{*}{$\begin{array}{c}\text { Designer specifies } \\
\text { ER/SR product if } \\
\text { project criteria and } \\
\text { ER/SR attributes } \\
\text { align and if } \\
\text { suitable product is } \\
\text { available }\end{array}$} \\
\hline & $\begin{array}{c}\text { Professional } \\
\text { Ethics }\end{array}$ & $\begin{array}{c}\text { Personal } \\
\text { responsibility to } \\
\text { educate client and } \\
\text { use ER/SR }\end{array}$ & $\begin{array}{l}\text { Designer's beliefs } \\
\text { in conflict with } \\
\text { company }\end{array}$ & \\
\hline & $\begin{array}{c}\text { Holistic } \\
\text { Approach }\end{array}$ & $\begin{array}{l}\text { Sustainable design } \\
\text { concept; LCA, } \\
\text { HSW issues }\end{array}$ & $\begin{array}{c}\text { Designer not aware } \\
\text { of choices, } \\
\text { evaluative tools }\end{array}$ & \\
\hline
\end{tabular}

In general practice, respondents' ranking of the importance of social responsibility did seem to be significantly linked with their standard approaches of incorporating sustainable design strategies. Furthermore, there was a link between ranking of the importance of social responsibility and the extent to which sustainable design practice was a standard project approach. Designers 
working on commercial projects seemed to be using sustainable design because this was a required approach rather than on the basis of their own convictions. The indication that sustainable outcomes are required in commercial projects is consistent with the fact that the commercial field is more regulated than residential design, and a commercial project is more likely to be part of a green building program.

Both qualitative and quantitative responses suggest that designers and their project work environments are at various stages in the development of sustainable practice. On the one hand, designers are motivated by external factors such as client preferences, project requirements, company management and standards, market information, and third-party certifications and testing data. On the other hand, many bring internal convictions for environmental and social responsibility through a personal view of the world, an understanding of professional ethics, or a holistic design approach. Seeking a balance between these factors was a common response. Some outcome scenarios were provisional or situational and occurred in the context of ambivalence of one or more parties.

The following model is instructive in understanding these dynamics.

\section{Limitations and recommendations for future study}

The web-based survey yielded a low number of responses, and since a randomly selected sample was not obtainable, it is not possible to speak to the objectivity of the participants. Individuals who had an interest in social responsibility may have been more likely to respond to the questionnaire.

More study is needed to explore the possible relationships between project type, social responsibility and sustainable design practice. Also of interest is whether specification of sustainable textiles or other product types generalizes to broader sustainable design practices. Other variables that could be explored include designers' length of experience and amount of international project work. The length of the questionnaire should be shortened to focus on targeted categories for the purpose of developing an instrument for evaluating social responsibility in interior design practice.

\section{Conclusions}

Interior design along with other professions in the building design and construction industry is in the process of changing the paradigm of how issues of social responsibility are addressed. Traditionally, professional and ethical standards of the interior design discipline have required that practitioners take responsibility for the consequences of decisions related to the health and safety of the public, e.g., individuals using and occupying the spaces they design. Although not yet mandated in the U.S., this same requirement is being extended in the European Union to individuals involved at all levels of the supply chain [20]. Triad models are evolving to be three dimensional and even four dimensional addressing life cycle impacts over time. Based on the trends toward an increasingly global perspective, it is not unreasonable to assume an increase 
in policy and regulation directed more specifically at both environmentally and socially responsible impacts and practice. This study supports that standard or best practice mandates may minimize or eliminate real or perceived obstacles to environmentally responsible and socially responsible decisions.

\section{References}

[1] Spiegel, R. \& Meadows, D., Green Building Materials: A Guide to Product Selection and Specification, John Wiley \& Sons: New Jersey, 2006.

[2] Elkington, J., Cannibals with Forks: The Triple Bottom Line of $21^{\text {st }}$ Century Business, Capstone Publishing Ltd.: Oxford, UK, 1999.

[3] Lovins, A. \& Lovins, L. H., Natural Capitalism: Creating the Next Industrial Revolution, Little, Brown \& Co.: New York, 1999.

[4] Bonda, P. \& Sosnowchik, K., Sustainable Commercial Interiors, John Wiley \& Sons: New Jersey, 2007.

[5] Pearson, J., Design \& Sustainability: Opportunities for Systemic Transformation, GreenBlue: Charlottesville, VA., 2006. Online. www.greenblue.org/PDFs/PEARSON Design+Sustainability.pdf

[6] Dunning, D. \& Zander, R., A vision revisited: Sustainable product design + evaluation. The Green Guide to NeoCon ${ }^{\circledR} 2008$, developed for Interiors \& Sources ${ }^{\circledR}$ by The Green ${ }^{\mathrm{TM}}$ Standard, pp. 24-28, 2008. Online. www.isdesignet.com/articles/detail

[7] Pearson, J., Design \& Sustainability: Opportunities for Systemic Transformation. GreenBlue: Charlottesville, VA., 2006. Online. www.greenblue.org/PDFs/PEARSON Design+Sustainability.pdf

[8] Wendt, A. Building for people: Integrating social justice into green design. Environmental Building News, 18(10), pp. 1, 10-15, 2009.

[9] Beecher, M. A., What's new? What's now? What's next? Interiors \& Sources, (January-February), $2003 . \quad$ Online. www.interiorsandsources.com/articles/detail.aspx? contentID $=3776$

[10] Kang, M. \& Guerin, D., The state of environmentally sustainable interior design practice. Proceedings of the Interior Design Educators Council (IDEC) 2006 Annual Conference, pp. 43-47. Online. www.idec.org/pdf/06ConferenceProceedings.pdf

[11] Steig, C., The Sustainability Gap. Journal of Interior Design, 32(1), pp. viixxi, 2006.

[12] Crane, T. J., Sustainable Design as Second Nature Incorporating Sustainability into the Interior Design Curriculum. Thesis (M.F.A.)Florida State University, 2008. Online. http://etd.lib.fsu.edu/ theses/available/etd-07122008-140432.

[13] Jones, L., (ed). Environmentally Responsible Design: Green and Sustainable Design for Interior Designers, John Wiley \& Sons: New Jersey, 2008.

[14] Elkington, J., Cannibals with Forks: The Triple Bottom Line of $21^{\text {st }}$ Century Business, Capstone Publishing Ltd.: Oxford, UK, 1999. 
[15] Bonda, P. \& Sosnowchik, K., Sustainable Commercial Interiors, John Wiley \& Sons: Hoboken, New Jersey, 2007.

[16] McDonald-Stewart, L. Personal communication, 20 July 2009, Founder and Editor, PLiNTH \& CHiNTZ, The Online Interior Design Magazine, Dallas, Texas.

[17] Ryan, G. W. \& Bernard, H. R., Techniques to Identify Themes. Field Methods, 15(1), pp. 85-109, 2003.

[18] The Sustainable Textile Standard, www.greenblue.org/activities_stm.html

[19] Steig, C., "The Sustainability Gap. Journal of Interior Design, 32(1), pp. vii-xxi, 2006.

[20] Dunning, D. \& Zander, R., A vision revisited: Sustainable product design + evaluation. The Green Guide to NeoCon ${ }^{\circledR} 2008$, developed for Interiors \& Sources ${ }^{\circledR}$ by The Green ${ }^{\mathrm{TM}}$ Standard, pp. 24-28, 2008. Online. www.isdesignet.com/articles/detail 